\title{
Cetuximab Enhanced the Cytotoxic Activity of Immune Cells during Treatment of Colorectal Cancer
}

\author{
Lin Wang $^{\mathrm{a}}$ Yingfeng Weja ${ }^{\mathrm{a}, \mathrm{b}}$ Weijia Fang ${ }^{\mathrm{c}}$ Chong Lu $^{\mathrm{a}}$ Jianing Chen ${ }^{\mathrm{a}}$ \\ Guangying Cui ${ }^{\mathrm{a}}$ Hongyan Diao ${ }^{\mathrm{a}}$
}

\begin{abstract}
aState Key Laboratory for Diagnosis and Treatment of Infectious Diseases, Collaborative Innovation center for Diagnosis and Treatment of Infectious Diseases, The First Affiliated Hospital, College of Medicine, Zhejiang University, Hangzhou, 'Department of gastroenterology, Ganzhou People's Hospital, Ganzhou, Jiangxi, 'Cancer Biotherapy Center, First Affiliated Hospital, School of Medicine, Zhejiang University, Hangzhou, China
\end{abstract}

\section{Key Words}

Colorectal cancer $\bullet$ Cetuximab $\bullet$ NK cells $\cdot \mathrm{CD}^{+}+\mathrm{T}$ cells

\begin{abstract}
Background/Aims: Cetuximab is a chimeric IgG1 monoclonal antibody which targets the extracellular domain of epidermal growth factor receptor. This antibody is widely used for colorectal cancer (CRC) treatment but its influence on the immune system is incompletely understood. Methods: The immune influence of cetuximab therapy in CRC patients was investigated by analyzing peripheral blood mononuclear cells using flow cytometry. We undertook in vitro cytotoxicity and cytokine-profile assays to ascertain the immunomodulatory effect of cetuximab treatment. Results: The number of $\mathrm{CD}^{+} \mathrm{T}, \mathrm{CD} 8^{+} \mathrm{T}$, and natural killer (NK) cells was increased significantly and T-regulatory cells reduced gradually after cetuximab treatment. Percentage of $\mathrm{CD}^{+}{ }^{+} \mathrm{T}$, natural killer T (NKT)-like, invariant NKT, and dendritic cells was similar between baseline patients and cetuximab patients. Expression of CD137 on NK and $\mathrm{CD}^{+} \mathrm{T}$ cells was increased significantly after 4 weeks of cetuximab therapy. In vitro cetuximab treatment markedly increased expression of CD137 and CD107a on NK and CD8 ${ }^{+}$ $T$ cells. Cetuximab treatment promoted the cytotoxic activity of NK and $C D 8^{+} T$ cells against tumor cells. Conclusion: Cetuximab treatment promotes activation of the immune response but alleviates immunosuppression: this might be the underlying anti-CRC effect of cetuximab.

(C) 2017 The Author(s)

Published by S. Karger AG, Basel

\section{Introduction}

Colorectal cancer (CRC) carries a high mortality worldwide. Surgery is first-line treatment for CRC but up to $30-40 \%$ of patients relapse within the first few years after initial surgery [1]. Also, it has been reported that $\approx 60 \%$ CRC patients will go on to suffer from

Hongyan Diao

State Key Laboratory for Diagnosis and Treatment of Infectious Diseases,

The First Affiliated Hospital, College of Medicine, Zhejiang University, Hangzhou (China) E-Mail diaohy@zju.edu.cn
\end{abstract}

KARGER 


\section{Cellular Physiology Cell Physiol Biochem 2017;44:1038-1050 \begin{tabular}{l|l} 
and Biochemistry 10.1159/000485404 & $\begin{array}{l}\text { O 2017 The Author(s). Published by S. Karger AG, Basel } \\
\text { www.karger.com/cpb }\end{array}$
\end{tabular} \\ Wang et al.: Immunological Characteristics of Cetuximab Treatment in CRC}

tumor metastasis [2]. Importantly, studies have indicated a high prevalence of mortality, recurrence and metastasis of CRC to be associated with immunocompromised patients [3, 4]. One epidemiologic survey showed low activity of natural killer (NK) cells to be associated with an increased risk of cancer [5, 6], and that infiltration of $\mathrm{CD}^{+} \mathrm{T}$ cells and NK cells are closely related to the clinical outcome of CRC [7]. One study demonstrated that NK cells can kill human tumor cells isolated immediately from colon carcinomas [8]. Moreover, NK cells can serve as effective immunotherapy for patients with metastatic CRC. For example, the adoptive transfer of $\mathrm{NK}$ cells to patients is an emerging method to treat the metastasis of CRC [6].

Cetuximab is a chimeric human-mouse anti-epidermal growth factor receptor (EGFR) immunoglobulin (Ig)G1 monoclonal antibody. It has been used to inhibit the proliferation, invasion, and metastasis of tumor cells [9-11]. Cetuximab was approved recently by the US Food and Drug Administration for first-line treatment of advanced CRC [12]. By crosslinking CD16a (Fc $\gamma$ RIIIa), cetuximab mediates the crosstalk between NK cells and dendritic cells (DCs), which is important for the induction of antitumor cellular immunity [13]. Cetuximabinduced activation of NK cells can upregulate expression of the costimulatory receptor CD137 (4-1BB), which is closely related to the efficiency of NK cells, and subsequently promotes $\mathrm{T}$ cell-based immunity in vitro [14-16]. Importantly, if DCs and NK cells are removed from peripheral blood, the antitumor activity of cetuximab is attenuated significantly. It has been shown that the number of $\mathrm{CD}^{+} \mathrm{T}$ cells is reduced significantly in patients with metastatic CRC compared with healthy individuals $[17,18]$. Some in vitro and mouse-model experiments have investigated the role of cetuximab in CRC treatment, but few studies have tried to determine the mechanism of action (MoA) of cetuximab during CRC treatment by analyzing the lymphocyte subsets of CRC patients [16, 19]. Mice-model experiments have suggested that cetuximab may target tumor cells by antibody-dependent cell-mediated cytotoxicity (ADCC) [20], and that cetuximab can intensify the ADCC antitumor activity of adoptive NK cells towards CRC with increased expression of the EGFR [15, 21-24]. Several studies have provided some information on how cetuximab acts on CRC in vitro, but the MoA of cetuximab during CRC treatment is not known due to a lack of in vivo studies.

Cetuximab is used widely for the treatment of metastatic CRC, but its MoA is not known. Thus, we analyzed the immune characteristics of the peripheral blood of CRC patients. We found that NK cells and $\mathrm{CD}^{+} \mathrm{T}$ cells have important roles in cetuximab treatment. These findings provide further understanding of the MoA of cetuximab during CRC treatment.

\section{Materials and Methods}

\section{Patients}

The study protocol conformed to Declaration of Helsinki guidelines and was approved by the Ethics Review Committee of the First Affiliated Hospital of Zhejiang University (Zhejiang, China) All individuals recruited in the study provided written informed consent. Written informed consent was obtained from all the enrolled participants. The study protocol was conducted with the approval of the Ethics Review Committee of the First Affiliated Hospital, Zhejiang University (Permit number: 2017-414), and the use of human blood samples was in accordance with the Guidelines of the Declaration of Helsinki.

Sixty-three (39 males and 24 females; 34-74 years) patients and 63 healthy controls (HCs: $36-70$ years) were

Table 1.Clinical characteristics of CRC patients $(n=63)$ and healthy controls $(n=63)$

\begin{tabular}{|c|c|c|c|c|}
\hline Variables & Healthy Controls & \multicolumn{2}{|c|}{ CRC patients } & $\mathrm{P}$ value \\
\hline Sex, n (M/F) & $39 / 24$ & \multicolumn{2}{|c|}{$40 / 23$} & 0.56 \\
\hline Median age (years, range) & $54(34-74)$ & \multicolumn{2}{|c|}{$48(36-70)$} & 0.19 \\
\hline TNM stage (n, \%) & 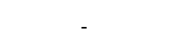 & $\begin{array}{cc}\text { G1/G2 } & 24 \\
\text { G3 } & 39\end{array}$ & $\begin{array}{l}4(38 \%) \\
(62 \%)\end{array}$ & - \\
\hline $\begin{array}{l}\text { White blood cells (mean, } 10^{9} / \mathrm{L} \text { ) } \\
\text { Lymphocyte (mean, \%) }\end{array}$ & $\begin{array}{c}5.9 \\
34.5 \%\end{array}$ & \multicolumn{2}{|c|}{$\begin{array}{l}6.7 \\
29.8 \%\end{array}$} & $\begin{array}{l}0.68 \\
0.34\end{array}$ \\
\hline Metastasis (n, \%) & - & $\begin{array}{l}\text { Liver sites only } \\
\text { Extra-hepatic sites }\end{array}$ & $\begin{array}{l}30(48 \%) \\
33(52 \%)\end{array}$ & - \\
\hline Primary tumor (n, \%) & - & $\begin{array}{lr}\text { Right colon } & 18 \\
\text { Left colon } & 2 \\
\text { Rectal } & 16\end{array}$ & $\begin{array}{l}8(28.6 \%) \\
29(46 \%) \\
(25.3 \%)\end{array}$ & - \\
\hline Differentiation (n, \%) & - & $\begin{array}{l}\text { Well } \\
\text { Poorly }\end{array}$ & $\begin{array}{l}8(44 \%) \\
8(56 \%)\end{array}$ & - \\
\hline Effective (n, \%) & & $50(79.34 \%$ & $\%)$ & \\
\hline
\end{tabular}


recruited at the First Affiliated Hospital of Zhejiang University. The patients and HCs were casematched for sex and age. All recruited CRC patients were at the advanced stage, with local infiltration as well as metastasis to lymph nodes and distant organs. Patients were divided into two groups: pre-cetuximab therapy ("baseline patients") and post-cetuximab therapy ("cetuximab patients"). The baseline clinical data are shown in Table 1.
Table 2. Cell surface marker phenotype of each immune cell subset assessed by flow cytometry

\begin{tabular}{|c|c|}
\hline Subset & Cell type(phenotype) \\
\hline \multirow{5}{*}{ Lymphocyte } & $\mathrm{T}$ cells $\left(\mathrm{CD}^{+}\right)$ \\
\hline & T cytotoxic cells $\left(\mathrm{CD} 3+\mathrm{CD} 4-\mathrm{CD}^{+}{ }^{+}\right)$ \\
\hline & NK cells(CD3-CD56+) \\
\hline & B cells (CD19+) \\
\hline & $\mathrm{DC}\left(\mathrm{BDCA} 1^{+}\right)$ \\
\hline \multirow{5}{*}{$\begin{array}{l}\text { T helper } \\
\text { NK cells }\end{array}$} & iNKT \\
\hline & $\mathrm{T}$ regulatory cells(CD4+CD $\left.25^{+} \mathrm{CD} 127^{-}\right)$ \\
\hline & CD $137+\mathrm{NK}$ cells $\left(\mathrm{CD} 3-\mathrm{CD} 56+\mathrm{CD} 107 \alpha^{+}\right)$ \\
\hline & CD $107 \alpha+\mathrm{NK}$ cells $\left(\mathrm{CD} 3-\mathrm{CD} 56^{+} \mathrm{CD} 137^{+}\right)$ \\
\hline & NKT like cells $\left(\mathrm{CD}^{+}{ }^{+} \mathrm{CD} 6^{+}\right)$ \\
\hline
\end{tabular}

\section{Cell lines}

The lines K562 (human leukemia cells) and HT-29 (colon carcinoma cells) were obtained from the Chinese Academy of Sciences (Beijing, China). Cells were cultured in Dulbecco's modified Eagle's medium (Invitrogen, Carlsbad, CA, USA) containing $100 \mathrm{U} / \mathrm{mL}$ penicillin, $100 \mu \mathrm{g} / \mathrm{mL}$ streptomycin, and 10\% fetal calf serum (Integro, Zaandam, The Netherlands). Cells were passaged every 5 days and maintained in an incubator at $37^{\circ} \mathrm{C}$ in an atmosphere of $5 \% \mathrm{CO}_{2}$.

\section{Study design}

Cetuximab (Erbitux ${ }^{\circledR}$, Merck, Darmstadt, Germany) was administered at $250 \mathrm{mg} / \mathrm{m}^{2}$ body weight every week after a loading dose of $400 \mathrm{mg} / \mathrm{m}^{2}$. Patients were monitored for toxicity every week and laboratory tests were undertaken before each chemotherapy administration. Dose modification and/ or temporary or permanent discontinuation of any drug was at the discretion of the attending physician. Treatment was continued until radiological progression according to RECIST 1.0 criteria or unacceptable toxicity. Assessment with helical computed tomography (CT) was carried out within 28 days before the first cycle of therapy and then every 8-12 weeks. Confirmatory evaluation was not planned. We collected samples from CRC patients 2-4 weeks after the start of cetuximab treatment, Clinical, imaging, biochemical and immunologic parameters were assessed at baseline, 2 weeks and 4 weeks). Symptoms, tumor size, tumor marker index, and lymphocyte subsets were evaluated, and adverse events documented.

\section{Flow cytometry}

Several monoclonal antibodies were used in the present study. Fluorescein isothiocyanate (FITC)anti-CD4, Phycoerythrin(PE)-anti-CD8, Pacific blue-anti-CD3, and Allophycocyanin (APC) -anti-CD25 were purchased from Beckman Coulter (Brea, CA, USA). APC-anti-CD127 was from eBioscience (San Diego, CA, USA). FITC-anti-CD56, PE-anti-CD19, PE-anti-BDCA1(CD1c), PE-anti-invariant natural killer T cells (iNKT), PE-anti-CD137, APC-anti-CD107, Phycoerythrin-Cy5 (PerCP-Cy5) -anti-CD137 and FITC-anti-CD8 were purchased from BD Biosciences (Franklin Lakes, NJ, USA). The cell surface marker phenotypes of each immune cell subset were listed in Table 2. Data were acquired on a FACSCanto ${ }^{\mathrm{TM}}$ II flow cytometer (BD Biosciences) and analyzed with FlowJo (Treestar, Ashland, OR, USA) or BD FACS Diva (BD Biosciences) software. The description of the staining step has been described previously.

\section{Isolation and culture of peripheral blood mononuclear cells (PBMCS)}

PBMCs were isolated from samples collected at 0 (baseline), 2 weeks and 4 weeks after cetuximab therapy. Acquired PBMCs were cultured at $2 \times 10^{6}$ cells $/ \mathrm{mL}$ in RPMI 1640 medium containing 10\% fetal bovine serum (FBS), with stimulation with $5 \mathrm{mg} / \mathrm{mL}$ cetuximab or bovine serum albumin (BSA) for 24 hours. 


\section{Cellular Physiology Cell Physiol Biochem 2017;44:1038-1050

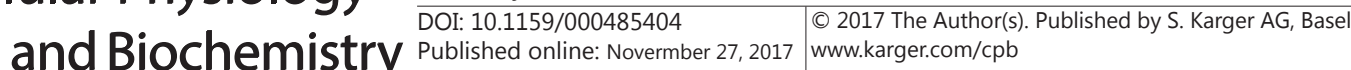

Wang et al.: Immunological Characteristics of Cetuximab Treatment in CRC

Cytotoxicity assay

Isolated PBMCs were cultured overnight with recombinant human interleukin (IL)-2 (10 ng/mL). Target cells (HT-29; Chinese Academy of Sciences) were pre-labeled with carboxyfluorescein succinimidyl ester (CFSE, Molecular Probes, Eugene, OA, USA) to differentiate them from PBMCs, as described previously [12]. PBMCs and HT-29 cells were harvested and seeded at an effector cell/target cell ratio of 10:1 for $12 \mathrm{~h}$ or $24 \mathrm{~h}$. Cells were harvested and stained with 7-amino-actinomycin D (7-AAD, Calbiochem, eBioscience, San Diego, CA), the cytotoxic activity was assayed by flow cytometr.

Cytotoxicity assay using a real-time cell analyzer assay (RTCA)

To analyze cytotoxicity to CRC cells, a RTCA was undertaken using an xCELLigence ${ }^{\mathrm{TM}}$ RTCA system (E-plate 16; ACEA Biosciences, San Diego, CA, USA). This system consisted of a RTCA impedance analyzer, a SP station, 16-well E-Plates, and a personal computer with RTCA software to control operation of the system. For each RTCA, $50 \mu \mathrm{L}$ of growth medium was added to each well for measurement of the impedance background. Then, $150 \mu \mathrm{L}$ of RPMI 1640 medium supplemented with $10 \%$ FBS and containing 2000 cells was added to each well, and cell growth was assessed for $\approx 3-4$ days.

HT-29 cells ( 5000 cells in $150 \mu \mathrm{L}$ medium/ well) were seeded in 16 -well plates in accordance with the xCELLigence RTCA instrument manual. PBMCs (250, 000 cells in $150 \mu \mathrm{L}$ medium/well) (effector cell/target cell $=50: 1)$ were added to the relevant wells. After $24 \mathrm{~h}$, cetuximab $(5 \mu \mathrm{M})$ was added and the experiment allowed to proceed for 3-4 days. An identical protocol was employed for NK cells and K562 cells.

Cytokine analyses

Cytokine levels in tissue homogenates and serum samples were assessed using an enzyme immunoassay according to manufacturer (Luminex, Austin, TX, USA) protocols.

\section{Statistical analyses}

Data were analyzed using Prism v6.0 (GraphPad, San Diego, CA, USA) and SPSS v19.0 (IBM, Armonk, NY, USA). Comparisons between the two groups were analyzed by the Student's $t$-test. Comparisons between several groups were analyzed by one-way ANOVA. Data are the mean \pm SD and are representative of at least two independent experiments. $\mathrm{P}<0.05$ was considered statistically significant.

\section{Results}

Cetuximab treatment changes the lymphocyte subset in the peripheral blood of CRC patients

To analyze the MoA of cetuximab during CRC treatment, we assessed the characteristics of lymphocytes in the peripheral blood of cetuximab-treated CRC patients. Compared with HCs, several lymphocyte subsets of peripheral blood were changed significantly. The number of $\mathrm{CD}^{+} \mathrm{T}$ cells, $\mathrm{CD}^{+} \mathrm{T}$ cells and NK cells was reduced significantly in baseline CRC patients compared with that in $\mathrm{HCs}\left(\mathrm{P}=0.009\right.$, Fig. 1,). However, the percentage of $\mathrm{CD}^{+} \mathrm{T}$ cells, natural killer T (NKT)-like cells, invariant natural killer T (iNKT) cells, and DCs in peripheral blood was similar between baseline CRC patients and HCs (Fig. 1C, Fig. 2). After 4 weeks of cetuximab treatment, the number of $\mathrm{CD}^{+} \mathrm{T}$ cells, $\mathrm{CD}^{+} \mathrm{T}$ cells and NK cells was increased significantly in cetuximab patients compared with baseline patients (Fig. 1A-B, D). These findings suggested that cetuximab might enhance anti-tumor immunity. To determine the effect of cetuximab upon immunity, we analyzed the number of T regulatory (Treg) cells, which often have immunosuppressive roles in tumors. Cetuximab treatment reduced the percentage of Treg cells in CRC patients gradually (Fig. 2C). Besides, the number of CD4 ${ }^{+} \mathrm{T}$ cells, NKT-like cells, iNKT cells and DCs in peripheral blood was not changed significantly after cetuximab treatment $(\mathrm{P}=0.34$, Fig. $1 \mathrm{C}, 2 \mathrm{~A}-\mathrm{B}, \mathrm{D})$. Collectively, these results suggested that the effect of $\mathrm{CD}^{+} \mathrm{T}, \mathrm{CD}^{+} \mathrm{T}$ and $\mathrm{NK}$ cells in peripheral blood was related to an immunoregulatory function of cetuximab. 


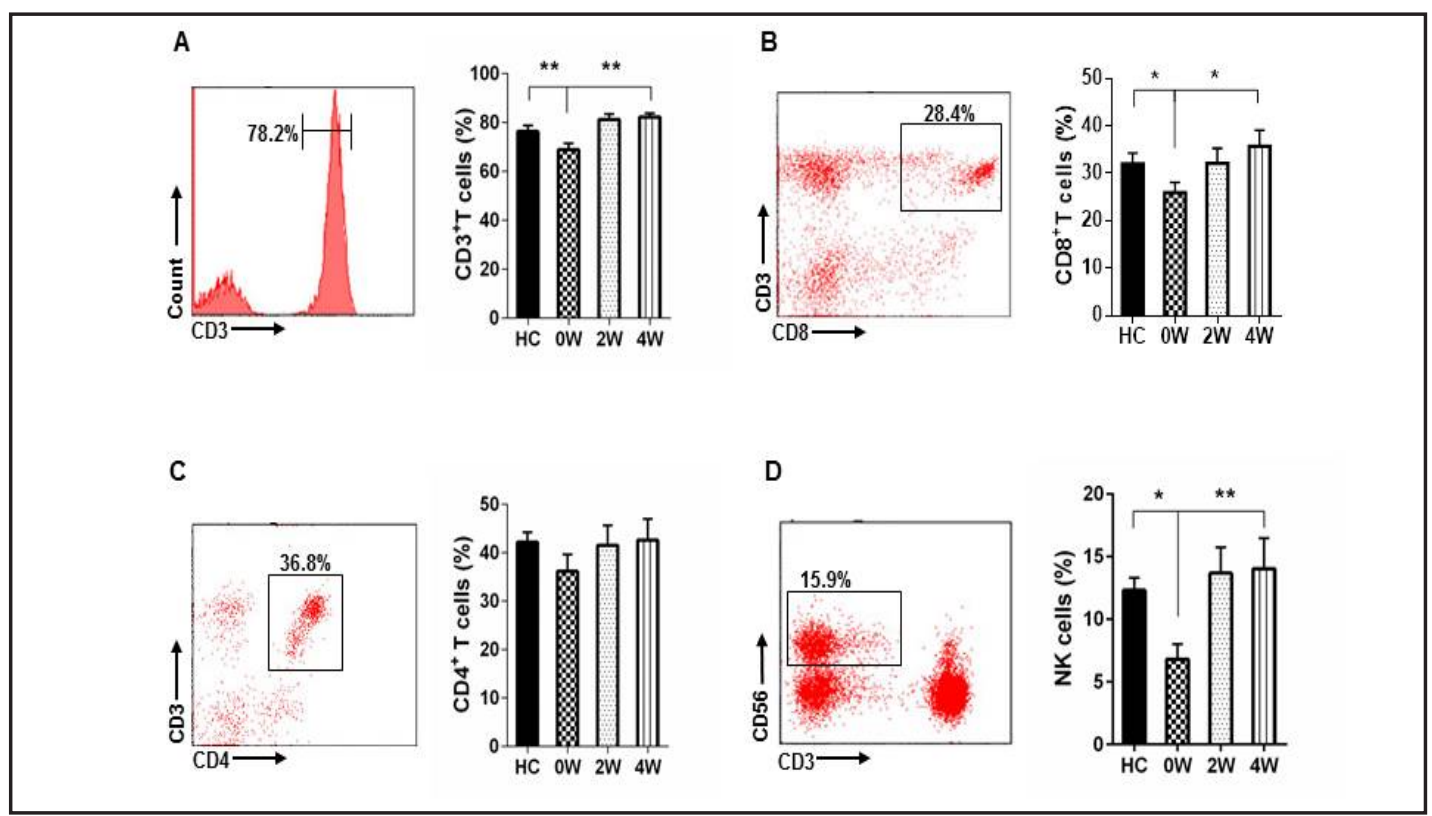

Fig. 1. Proportions of $\mathrm{CD}^{+}, \mathrm{CD}^{+}, \mathrm{CD}^{+}$and $\mathrm{NK}$ cells in the peripheral blood of CRC patients. (A-C) Left: distribution of $\mathrm{CD}^{+}, \mathrm{CD}^{+}$and $\mathrm{CD}^{+}$cells in the lymphocyte population of baseline patients. Right: proportions of $\mathrm{CD}^{+}, \mathrm{CD}^{+}$and $\mathrm{CD} 4^{+}$cells in lymphocyte populations of cetuximab patients at different time points of the disease and in HCs (n = 63). (D) Left: distribution of NK cells in lymphocyte populations of baseline patients. Right: Percentage of NK cells in lymphocyte populations of cetuximab patients at different time points compared with HCs. Statistical analyses were done using the paired t-test. The horizontal bar represents the standard error. ${ }^{*} \mathrm{p}<0.05$; $^{* *} \mathrm{p}<0.01$; $^{* *} \mathrm{p}<0.001$.
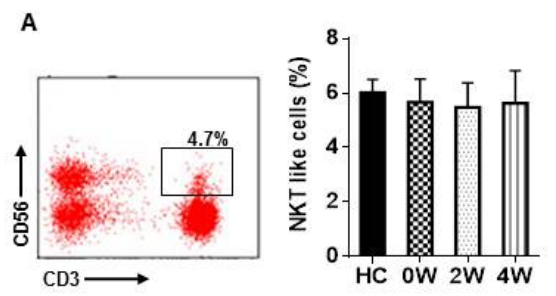

C
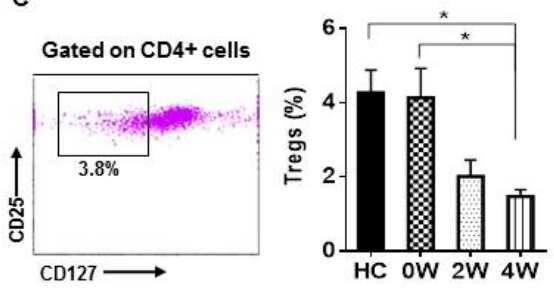
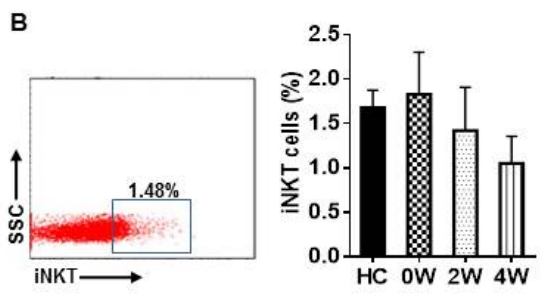

D

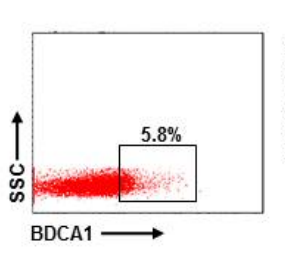

Fig. 2. Percentage of NKT-like cells, Treg cells, iNKT cells and DCs in the peripheral blood of CRC patients(A-D) Left: distribution of NKT-like cells, Treg cells, iNKT cells and DCs in lymphocyte populations of baseline patients $(n=63)$. Right: proportions of NKT-like cells, Treg cells, iNKT cells and DCs in lymphocyte populations of CRC cetuximab patients at different time points of the disease and in HCs ( $\mathrm{n}=63)$. Statistical analyses were done using the paired t-test. The horizontal bar represents the standard error. ${ }^{*} \mathrm{p}<0.05$; ${ }^{* *} \mathrm{p}<0.01 ;{ }^{* *} \mathrm{p}<0.001$. 
Cetuximab therapy induced CD137 expression on NK cells and CD8 ${ }^{+} T$ cells in CRC patients

Recent studies have shown that CD137 is a member of the recently discovered tumor necrosis factor receptor (TNFR) superfamily. CD137 is involved in the NK cell-mediated effects of killing tumor cells [25]. Thus, we assessed the CD137 expression of NK cells in cetuximab-treated CRC patients.

Cetuximab treatment increased the CD137 expression on NK cells among CRC patients gradually (Fig. 3A). Cetuximab treatment also increased the CD137 expression of CD8 ${ }^{+} \mathrm{T}$ cells in CRC patients (Fig. 3B). There was no notable difference in CD137 expression on NKTlike and iNKT cells between HCs and baseline patients, and cetuximab treatment made no significant difference to the CD137 expression of NKT cells in CRC patients (Fig. 3C, D). These data suggested that cetuximab enhanced the effector immune function of NK cells in CRC patients in vitro.

Effects of cetuximab treatment on expression of CD107a and CD137 on NK cells and CD8 ${ }^{+}$ T cells in vitro

CD107a has been shown to be a marker of the degranulation of lymphocytes such as $\mathrm{CD}^{+} \mathrm{T}$ and NK cells, and may also have a role in the differentiation and metastasis of tumor cells. Thus, we further analyzed the effects of cetuximab treatment on expression of CD107a and CD137 on NK cells and CD8 ${ }^{+} \mathrm{T}$ cells in vitro.

Compared with HCs, cetuximab treatment increased the percentage of NK cells and $\mathrm{CD}^{+} \mathrm{T}$ cells in the PBMCs of CRC patients significantly (P=0.014, Fig. 5A, D).

Moreover, cetuximab treatment increased expression of CD137 and CD107a on NK cells and CD8 ${ }^{+} \mathrm{T}$ cells from the PBMCs of CRC patients significantly (Fig.4A-D, 5B-C, 5E-F).

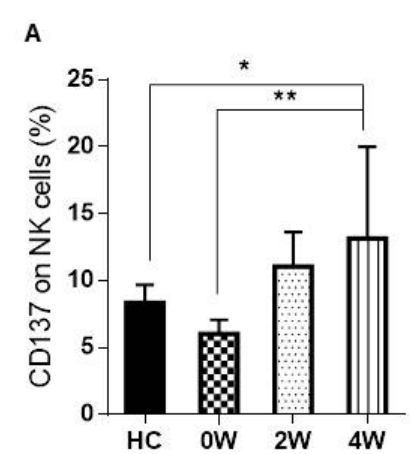

C

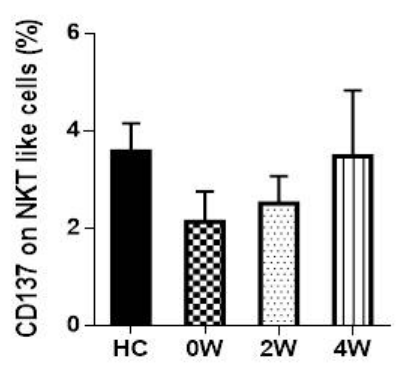

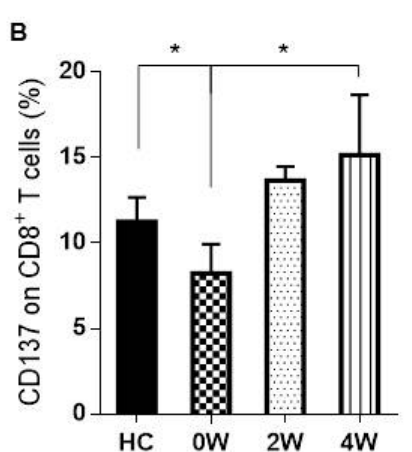

D

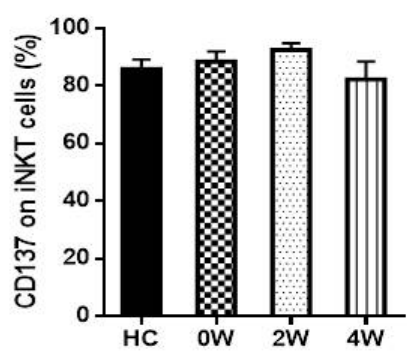

Fig. 3. Proportion of CD137 on NK cells, $C D 8^{+} \mathrm{T}$ cells, NKT-like cells and iNKT cells in the peripheral blood of CRC patients compared with HCs in vivo.CD137 expression on NK cells, CD8 ${ }^{+} \mathrm{T}$ cells, NKT-like cells and iNKT cells was evaluated by surface staining and flow cytometry. (A) The ratios of CD137 on NK cells during cetuximab treatment at different times points were compared with those of HCs. (B) The percentage of CD137-expressing CD8 ${ }^{+}$T cells on. (C) The percentage of CD137-expressing NKTlike cells on. (D) The percentage of CD137-expressing iNKT cells on. Statistical analyses were done using the paired t-test. The horizontal bar represents the standard error. ${ }^{*} \mathrm{p}<0.05 ;{ }^{* *} \mathrm{p}<0.01 ;{ }^{* * *} \mathrm{p}<0.001$. 


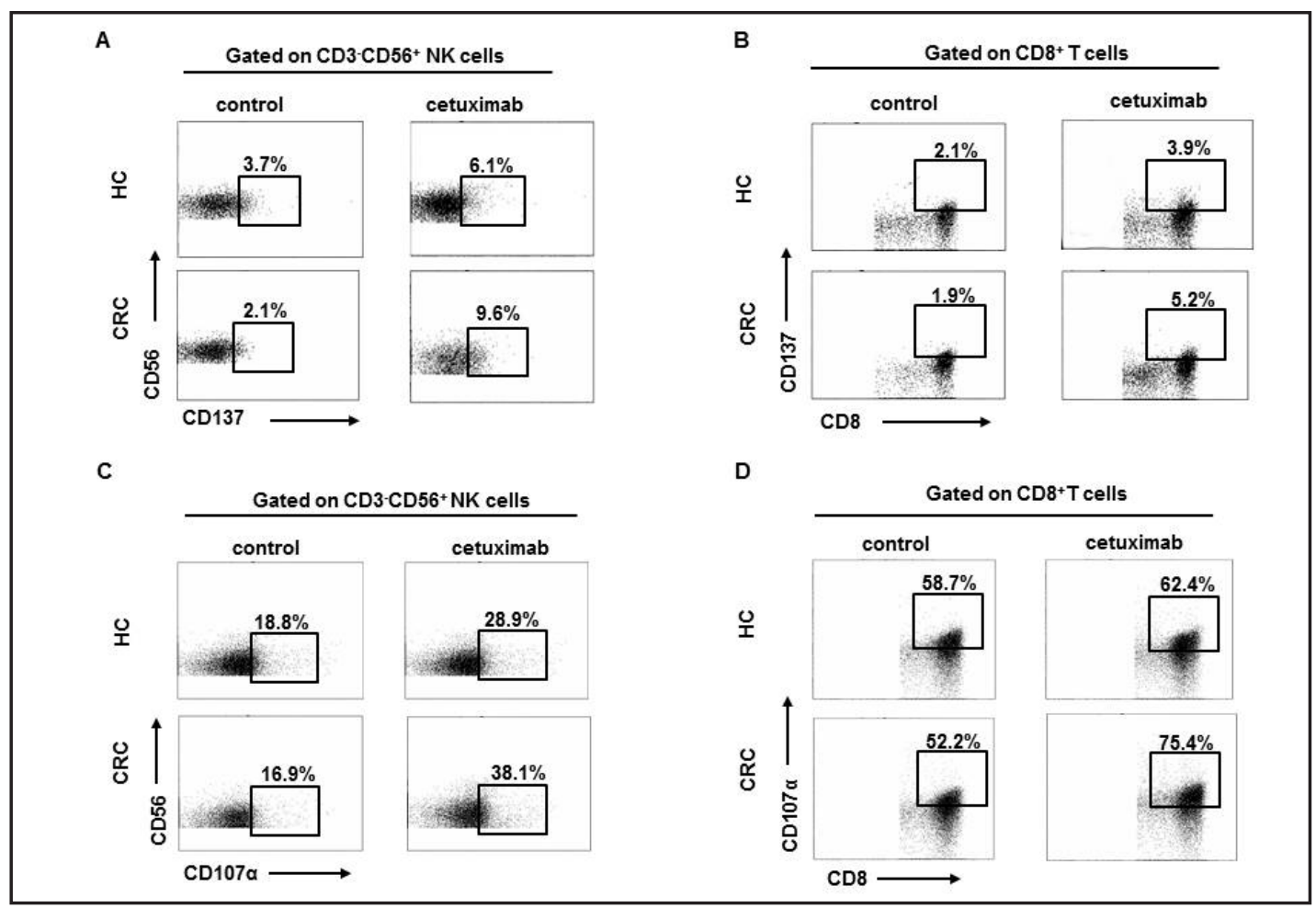

Fig. 4. The proportion of CD137 and CD107 $\alpha$ on NK cells and CD8 ${ }^{+} \mathrm{T}$ cells stimulated with cetuximab in vitro was counted.Fresh isolated NK cells and CD8 ${ }^{+} \mathrm{T}$ cells from $\mathrm{HC}$ and CRC $(0$ weeks) were incubated with cetuximab $(5.0 \mu \mathrm{g} / \mathrm{mL})$ for $24 \mathrm{~h}$ and intracellular CD137 and CD107 $\alpha$ expression on NK cells and CD8 ${ }^{+} \mathrm{T}$ cells was evaluated by flow cytometry. The representative flow cytometric scatterplot of CD137 on the CD3CD56 lymphocytes (A) and on CD8 ${ }^{+}$T cells (B). The representative flow cytometric scatterplot of CD107 on the CD3-CD56+ lymphocytes (C) and on CD8 ${ }^{+}$T cells (D).

However, cetuximab treatment had no significant effect on expression of CD137 or CD107a on the NK cells and CD8 ${ }^{+} \mathrm{T}$ cells of HCs (Fig. 4A-D, 5B-C, 5E-F).

\section{Cetuximab enhanced cytotoxicity against CRC cells}

An in vitro experiment was designed and conducted to further investigate if cetuximab can enhance the toxicity of lymphocytes against CRC cells. Cetuximab treatment could significantly increase the cytotoxicity of HC- and CRC patient-derived PBMCs to HT-29 cells (Fig.6A, B).

To confirm the role of NK cells in the cetuximab-enhanced cytotoxicity against tumor cells, RTCAs were used to carry out further experiments. Cetuximab treatment could enhance the cytotoxic effect of HC- and CRC patient-derived PBMCs on HT-29 cells (Fig. 6C). RTCA data showed that cetuximab treatment could enhance the cytotoxic effect of HC- and CRC patient-derived NK cells on K562 cells (Fig. 6D).

In summary, these data confirmed as it was previously demonstrated that cetuximab treatment could promote the cytotoxic activity of PBMCs and NK cells against tumor cells, which could be the underlying MoA of cetuximab against CRC cells [15].

\section{Cetuximab treatment affected the cytokine profile in plasma}

To further study the enhanced effect of cetuximab on the immune response of CRC patients, plasma levels of IL-6, interferon (IFN)- $\gamma$ and IL-10 were measured.

Cetuximab treatment could increase the IFN- $\gamma$ level in the plasma of CRC patients gradually (Fig. 7B). Levels of IL-6 and IL-10 were increased significantly in baseline patients

\section{KARGER}




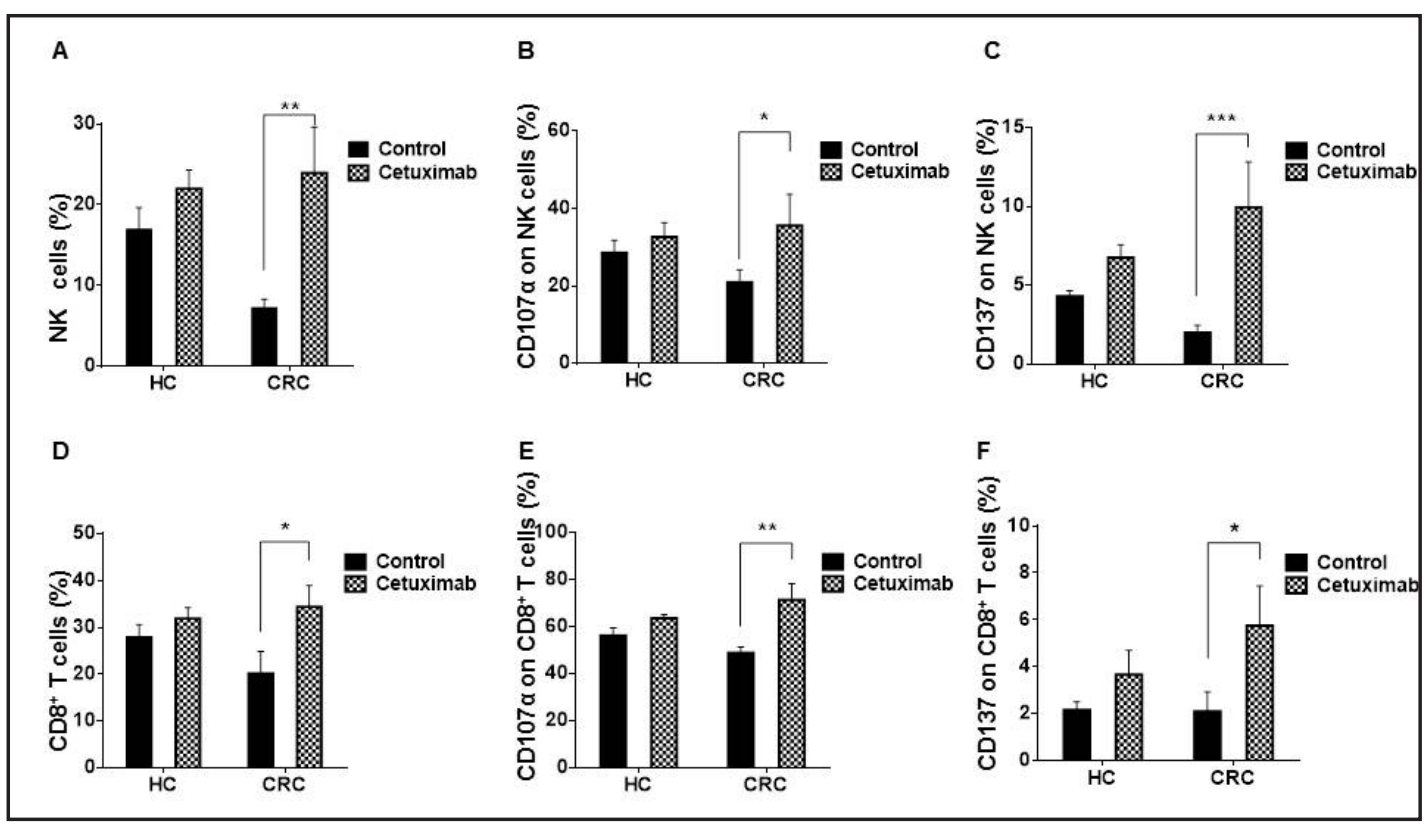

Fig. 5. NK cells and CD8 ${ }^{+} \mathrm{T}$ cells in peripheral blood were incubated for $24 \mathrm{~h}$, and the proportion of CD137 and CD107 $\alpha$ on NK cells and CD8 ${ }^{+} \mathrm{T}$ cells stimulated with cetuximab in vitro was counted.NK cells and

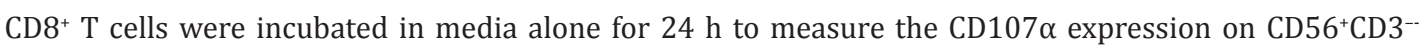
-gated NK cells or CD8 ${ }^{+} \mathrm{T}$ cells, or were incubated with cetuximab $(5.0 \mu \mathrm{g} / \mathrm{mL})$ for $24 \mathrm{~h}$ to measure the CD137 expression on $\mathrm{CD}^{2} 6^{+} \mathrm{CD}^{-}$-gated NK cells. The percentage of NK cells and CD8 ${ }^{+} \mathrm{T}$ cells in CRC patients compared with HCs (A and D). CD137 expression on NK cells and CD8 ${ }^{+} \mathrm{T}$ cells were measured by staining and flow cytometry. ( $\mathrm{C}$ and F) The percentage of CD107 $\alpha$ expressed on NK cells and CD8 ${ }^{+} \mathrm{T}$ cells from baseline patients were compared with those of HCs, stimulated with cetuximab ( $5 \mu \mathrm{g} / \mathrm{mL})(\mathrm{B}$ and E). The percentage of CD107 $\alpha$ expressed on NK cells was compared with that in HCs. Data are shown as mean \pm SEM. ${ }^{*}$ p $<0.05$ $;^{* *} \mathrm{p}<0.01 ;{ }^{* * *} \mathrm{p}<0.001$

compared with HCs subjects, but cetuximab treatment reduced the levels of IL-6 and IL-10 gradually (P=0.012, Fig. 7A, C). Studies [26-28] have shown IFN- $\gamma$ to be a primary cytokine of NK cells and IL-10 to be an important cytokine of Treg cells. Thus, the plasma cytokine level is in accordance with the proportion of NK cells and Treg cells in peripheral blood, which further suggests that cetuximab treatment promotes activation of the immune response and alleviates immunosuppression.

\section{Discussion}

The impact of CRC has been a global health issue over the past decade [29, 30]. Studies have suggested that a high prevalence of mortality, recurrence and metastasis of CRC is associated with immunocompromised patients.

Cetuximab is a specific monoclonal antibody that can be used to inhibit the proliferation, invasion, and metastasis of tumor cells. Several studies have reported that cetuximab is effective in CRC treatment, but the underlying MoA is not known. Thus, we attempted to determine the anti-CRC MoA of cetuximab by analyzing the immunologic characteristics of CRC patients.

We found that the number of $\mathrm{CD}^{+}{ }^{+} \mathrm{T}$ cells, $\mathrm{CD}^{+} \mathrm{T}$ cells and $\mathrm{NK}$ cells was increased significantly after cetuximab treatment in CRC patients. However, the percentage of CD4 ${ }^{+}$ T cells, NKT-like cells, iNKT cells and DCs in peripheral blood was similar between baseline patients and HCs. CD137 expression on the NK cells and CD8 ${ }^{+} \mathrm{T}$ cells of CRC patients was increased significantly after 4 weeks of cetuximab therapy. Furthermore, cetuximab 


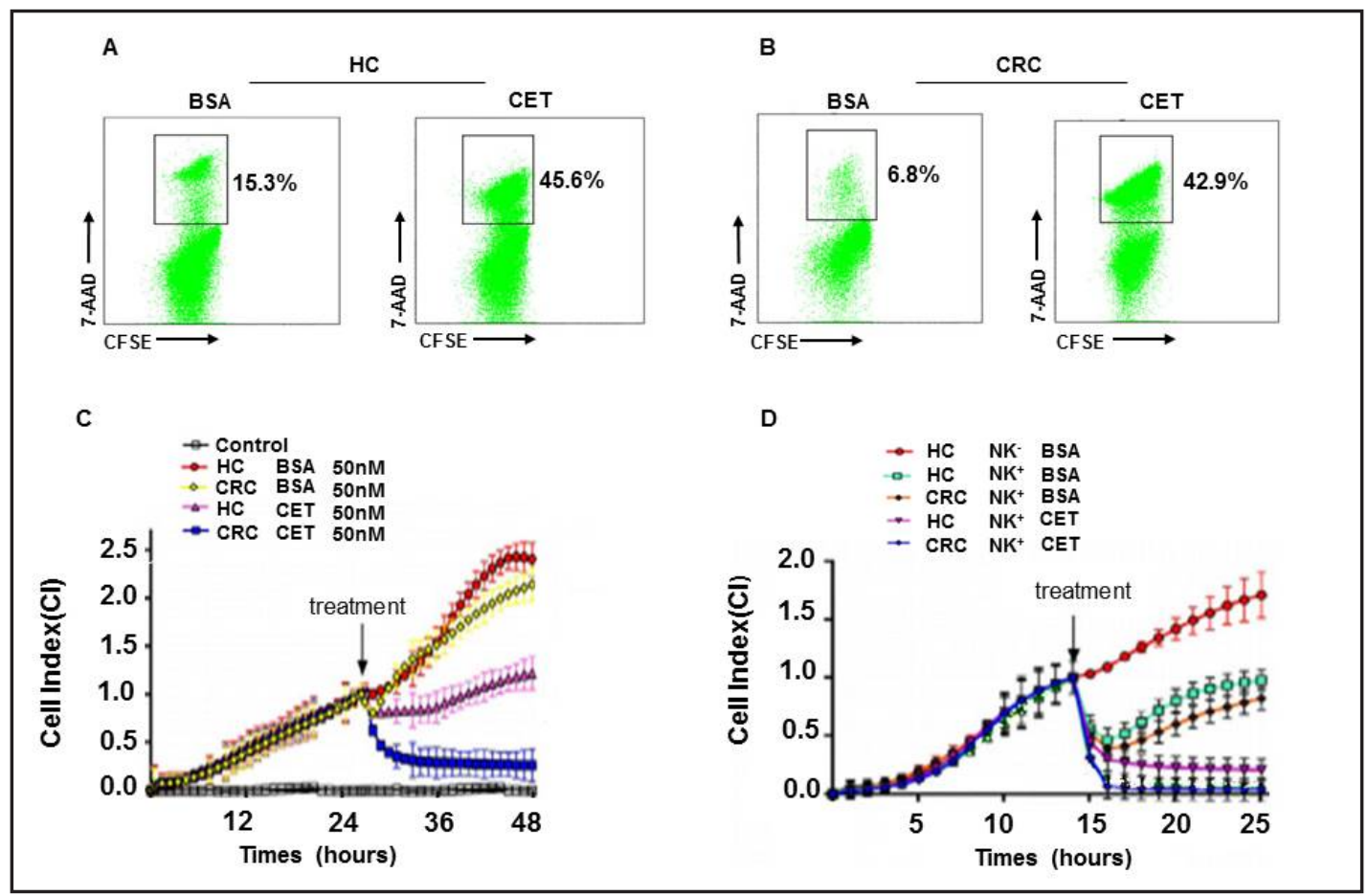

Fig. 6. Cetuximab enhanced the cytotoxicity of NK cells towards EGFR ${ }^{+}$tumor targets (HT-29) and killing of K562 cells in vitro.(A) PBMCs from HCs were stimulated for $48 \mathrm{~h}$ in vitro. In the presence of cetuximab or not, a cytotoxic assay with target HT-29 cells denoted as the 7-AAD-positive rate was analyzed by flow cytometry. (B) PBMCs from CRC patients were stimulated for $48 \mathrm{~h}$ in vitro. In the presence of cetuximab or not, the cytotoxic assay with target HT-29 cells was denoted as the 7-AAD-positive rate as analyzed by flow cytometry. (C) Cetuximab-mediated PBMC activity against HT-29 cells at different effector cell: target cell ratios. PBMCs were stimulated for $48 \mathrm{~h}$ in vitro. Real-time monitoring of the cytotoxic activity of PBMCs against HT29 cells using a RTCA-16 system. PBMCs from baseline patients and HCs in the presence of cetuximab or not. (D) Real-time monitoring of the cytotoxic activity of NK cells on K562 cells using a RTCA-16 system. NK cells were purified from PBMCs by anti-PE microbeads according to a MACS separation manual. NK cells isolated from PBMCs were stimulated for $48 \mathrm{~h}$ in vitro. Cytotoxicity of NK cells was detected after K562 had been co-cultured with NK cells in the presence of cetuximab or not. Data presented are the means \pm SEM. $* \mathrm{P}<0.05 * * \mathrm{P}<0.01$, one-way ANOVA.

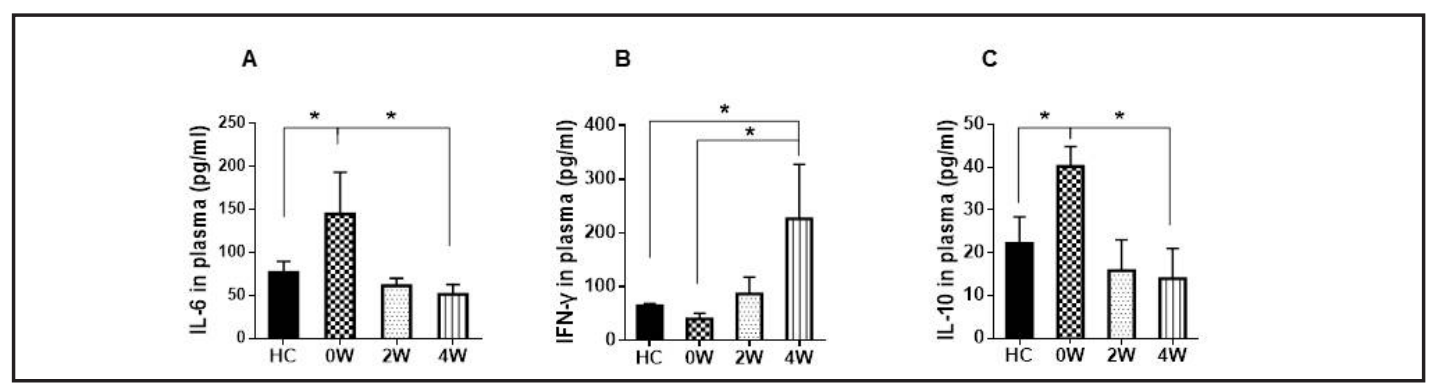

Fig. 7. Plasma levels of IL-6, IL-10, TNF- $\alpha$ and IFN- $\gamma$ in baseline patients after cetuximab therapy and comparison with those of HCs. Cytokine profile of plasma was analyzed by the an enzyme immunoassay system. (A-C) reduction in the concentration of soluble IL-6, IL-10 and TNF- $\alpha$ in the plasma of 4 weektreated cetuximab patients compared with baseline patients and HCs $(n=63)$. Horizontal bar is the mean \pm SEM. (D) IFN- $\gamma$ levels in cetuximab patients was augmented compared with those in baseline patients and HCs. * $\mathrm{p}<0.05$ The data represent means \pm SEM, One-way ANOVA. 


\section{Cellular Physiology Cell Physiol Biochem 2017;44:1038-1050 \begin{tabular}{ll|l} 
and Biochemistry & $\begin{array}{l}\text { DOI 10.1159/000485404 } \\
\text { Published online: Novermber 27, } 2017\end{array}$ & $\begin{array}{l}\text { O 2017 The Author(s). Published by S. Karger AG, Basel } \\
\text { www.karger.com/cpb }\end{array}$ \\
\cline { 2 - 3 }
\end{tabular} \\ Wang et al.: Immunological Characteristics of Cetuximab Treatment in CRC}

treatment increased CD107a expression on NK cells and $\mathrm{CD}^{+} \mathrm{T}$ cells in CRC patients markedly. Cetuximab treatment could promote the cytotoxic activity of PBMCs and NK cells against tumor cells: this might be the underlying MoA of the anti-CRC effect of cetuximab.

Studies have demonstrated that downregulation of expression of activating cells and upregulation of expression of inhibitory cells occur in the early stages of CRC [15]. The low functionality of NK cells could prevent NK cells from attacking and eliminating tumor cells in the circulation at early and advanced stages of the disease. Also, an immune system characterized by dysregulated NK cells could be a fertile environment for tumor establishment. Cetuximab improves the overall survival of patients with metastatic CRC, which demonstrates the efficacy of cetuximab if used as monotherapy in patients with metastatic CRC. We speculated that cetuximab might regulate the immune state of CRC patients, and our study confirmed this speculation. We found that cetuximab exerted its antiCRC effect through regulation of the immune state, particularly the function of NK cells and CD8 ${ }^{+} \mathrm{T}$ cells.

NK cells are considered to be the most effective anti-tumor lymphocytes [31]. NK cells have been applied for the treatment of patients with advanced CRC refractory to standard treatment, and such treatment was effective and safe [32,33]. Besides, activated NK cells can kill tumor cells directly through perforin and granzymes or by inducing ADCC activity [34]. Furthermore, NK cells can produce cytokines such as IFN- $\gamma$, tumor necrosis factor- $\alpha$ (TNF- $\alpha$ ) and IL- 6 to enhance the antitumor effects and FasL/Fas-mediated apoptosis of tumor cells $[16,35]$. CD137 is a member of the TNFR family, which is expressed on activated T cells, NKTlike cells and NK cells $[36,37]$. Pre-clinical studies have revealed the antitumor properties of anti-CD137 monoclonal antibodies: they can enhance the activation and survival of tumorspecific CD8 ${ }^{+} \mathrm{T}$ cells, and increase the function of NK cells and DCs $[38,39]$. In the present study, the number of NK cells was increased significantly after cetuximab treatment, and expression of CD137 and CD107a on the NK cells of CRC patients was increased significantly after 4 weeks of cetuximab therapy. An in vitro experiment suggested that PBMCs and NK cells can promote the apoptosis of K562 cells. We also found that cetuximab treatment could promote the cytotoxic acivity of PBMCs and NK cells against tumor cells.

Cetuximab has been approved as first-line treatment of EGFR-positive metastatic CRC and as remedial treatment for other chemotherapy-failed CRC patients [40, 41]. One study showed that cetuximab treatment increased the percentage of NK cells dramatically in vitro [42]. Subsequently, NK cells could lyse tumor cells through ADCC activity [43]. Studies have also shown that cetuximab promotes the toxicity of NK cells against tumor cells in vitro [44]. CD137 expression on CD4 ${ }^{+} \mathrm{T}$ cells and $\mathrm{NK}$ cells is also increased significantly after cetuximab therapy in mice [38]. In the present study, cetuximab increased the percentage of CD137 on NK cells and CD8 ${ }^{+} \mathrm{T}$ cells, but had no significant impact on the CD137 expression of $\mathrm{CD} 4^{+} \mathrm{T}$ cells. This phenomenon might have been because cetuximab therapy could induce expansion of the number of T cells in CRC patients.

However, after cetuximab treatment, changes in lymphocyte subsets in vivo have not been investigated, so we conducted these studies. Consistent with a previous study, cetuximab treatment increased the number of $\mathrm{CD}^{+} \mathrm{T}, \mathrm{CD}^{+} \mathrm{T}$ and $\mathrm{NK}$ cells of CRC patients. Levels of CD137 and CD107a on NK cells and CD8 ${ }^{+} \mathrm{T}$ cells were increased markedly after cetuximab therapy. Also, the percentage of NKT-like cells was not changed significantly after cetuximab treatment. Treg cells often have immunosuppressive roles in tumors, and we found that cetuximab treatment reduced the percentage of Treg cells in the peripheral blood of CRC patients gradually. We inferred that cetuximab may inhibit the immunosuppressive effect of Tregs, thereby promoting the ability of immune cells to kill tumor cells. 


\section{Cellular Physiology Cell Physiol Biochem 2017;44:1038-1050 \begin{tabular}{l|l|l}
\hline DOI: 10.1159/000485404 & $\begin{array}{l}\text { C) } 2017 \text { The Author(s). Published by S. Karger AG, Basel } \\
\text { www.karger.com/cpb }\end{array}$
\end{tabular}}

Wang et al.: Immunological Characteristics of Cetuximab Treatment in CRC

\section{Conclusion}

The present study suggests that NK cells and $\mathrm{CD}^{+} \mathrm{T}$ cells are involved in the MoA of cetuximab during the treatment of metastatic CRC. Also, NK cells and CD8 ${ }^{+} \mathrm{T}$ cells may have important roles in the antitumor activity of cetuximab in vivo.

\section{Acknowledgements}

This work was supported by funds received from the National Natural Science Foundation of China (No. 81571953), Zhejiang Provincial Natural Science Foundation of China (LY16H190002), the National Hygiene Bureau and Zhejiang Province Co-construction Project (2015118507).

\section{Disclosure Statement}

The authors have stated explicitly that there are no conflicts of interest in connection with this article.

\section{References}

1 Walker AS, Johnson EK, Maykel JA, Stojadinovic A, Nissan A, Brucher B, Champagne BJ, Steele SR: Future Directions for the Early Detection of Colorectal Cancer Recurrence. J Cancer 2014;5:272-280.

-2 Zhao H, Xu Z, Qin H, Gao Z, Gao L: miR-30bregulates migration and invasion of human colorectal cancer via SIX1. Biochem J 2014;460:117-125.

-3 Santos MF, Mannam VK, Craft BS, Puneky LV, Sheehan NT, Lewis RE, Cruse JM: Comparative analysis of innate immune system function in metastatic breast, colorectal, and prostate cancer patients with circulating tumor cells. Exp Mol Pathol 2014;96:367-374.

4 Gharagozloo M, Kalantari H, Rezaei A, Maracy MR, Salehi M, Bahador A, Hassannejad N, Narimani M, Sanei MH, Bayat B, Ghazanfari H: The decrease in NKG2D+ Natural Killer cells in peripheral blood of patients with metastatic colorectal cancer. Bratisl Lek Listy 2015;116:296-301.

5 Jobin G, Rodriguez-Suarez R, Betito K: Association Between Natural Killer Cell Activity and Colorectal Cancer in High-risk Subjects Undergoing Colonoscopy. Gastroenterology 2017;53:980-987.

6 Garcia-Chagollan M, Jave-Suarez LF, Haramati J, Sanchez-Hernandez PE, Aguilar-Lemarroy A, Bueno-Topete MR, Pereira-Suarez AL, Fafutis-Morris M, Cid-Arregui A, del Toro-Arreola S: Substantial increase in the frequency of circulating CD4+NKG2D+ T cells in patients with cervical intraepithelial neoplasia grade $1 \mathrm{~J}$ Biomed Sci 2013;20:60.

7 Guo X, Zheng L, Jiang J, Zhao Y, Wang X, Shen M, Zhu F, Tian R, Shi C, Xu M, Li X, Peng F, Zhang H, Feng Y, Xie Y, Xu X, Jia W, He R, Xie C, Hu J, Ye D, Wang M, Qin R: Blocking NF-kappaB Is Essential for the Immunotherapeutic Effect of Recombinant IL18 in Pancreatic Cancer. Clin Cancer Res 2016;22:5939-5950.

8 Bhat R, Rommelaere J: NK-cell-dependent killing of colon carcinoma cells is mediated by natural cytotoxicity receptors (NCRs) and stimulated by parvovirus infection of target cells. BMC Cancer 2013;13:367.

9 Van Emburgh BO, Arena S, Siravegna G, Lazzari L, Crisafulli G, Corti G, Mussolin B, Baldi F, Buscarino M, Bartolini A, Valtorta E, Vidal J, Bellosillo B, Germano G, Pietrantonio F, Ponzetti A, Albanell J, Siena S, Sartore-Bianchi A, Di Nicolantonio F, Montagut C, Bardelli A: Acquired RAS or EGFR mutations and duration of response to EGFR blockade in colorectal cancer. Nat Commun 2016;7:13665.

10 Tashiro T, Okuyama H, Endo H, Kawada K, Ashida Y, Ohue M, Sakai Y, Inoue M: In vivo and ex vivo cetuximab sensitivity assay using three-dimensional primary culture system to stratify KRAS mutant colorectal cancer. PLoS One 2017;12:e174151. 


\section{Cellular Physiology Cell Physiol Biochem 2017;44:1038-1050

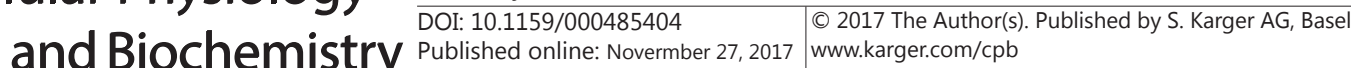

Wang et al.: Immunological Characteristics of Cetuximab Treatment in CRC

11 Kuppen PJ, Gorter A, Hagenaars M, Jonges LE, Giezeman-Smits KM, Nagelkerke JF, Fleuren G, van de Velde CJ: Role of NK cells in adoptive immunotherapy of metastatic colorectal cancer in a syngeneic rat model. Immunol Rev 2001;184:236-243.

12 Rajpal S, Venook AP: Targeted therapy in colorectal cancer. Clin Adv Hematol Oncol 2006;4:124-132.

-13 Kloss S, Chambron N, Gardlowski T, Weil S, Koch J, Esser R, Pogge von Strandmann E, Morgan MA, Arseniev L, Seitz O, Kohl U: Cetuximab Reconstitutes Pro-Inflammatory Cytokine Secretions and Tumor-Infiltrating Capabilities of sMICA-Inhibited NK Cells in HNSCC Tumor Spheroids. Front Immunol 2015;6:543.

$>14$ Srivastava RM, Trivedi S, Concha-Benavente F, Gibson SP, Reeder C, Ferrone S, Ferris RL: CD137 Stimulation Enhances Cetuximab-Induced Natural Killer: Dendritic Cell Priming of Antitumor T-Cell Immunity in Patients with Head and Neck Cancer. Clin Cancer Res 2017;23:707-716.

15 Rocca YS, Roberti MP, Julia EP, Pampena MB, Bruno L, Rivero S, Huertas E, Sanchez Loria F, Pairola A, Caignard A, Mordoh J, Levy EM: Phenotypic and Functional Dysregulated Blood NK Cells in Colorectal Cancer Patients Can Be Activated by Cetuximab Plus IL-2 or IL-15 . Front Immunol 2016;7:413.

16 Veluchamy JP, Lopez-Lastra S, Spanholtz J, Bohme F, Kok N, Heideman DA, Verheul HM, Di Santo JP, de Gruijl TD, van der Vliet HJ: In vivo Efficacy of Umbilical Cord Blood Stem Cell-Derived NK Cells in the Treatment of Metastatic Colorectal Cancer. Front Immunol 2017;8:87.

17 Hagland HR, Lea D, Watson MM, Soreide K: Correlation of Blood T-Cells to Intratumoural Density and Location of CD3+ and CD8+ T-Cells in Colorectal Cancer. Anticancer Res 2017;37:675-683.

18 Governa V, Trella E, Mele V, Tornillo L, Amicarella F, Cremonesi E, Muraro MG, Xu H, Droeser R, Daster SR, Bolli M, Rosso R, Oertli D, Eppenberger-Castori S, Terracciano L, Iezzi G, Spagnoli GC: The interplay between neutrophils and CD8+ T cells improves survival in human colorectal cancer. Clin Cancer Res 2017

19 Yan Z-h, Zheng X-f, Yi L, Wang J, Wang X-j, Wei P-j, Jia H-y, Zhou L-j, Zhao Y-l, Zhang H-t: CD137 is a useful marker for identifying CD4+T cell responses to Mycobacterium tuberculosis. Scand J Immunol 2017;85:372-380.

-20 Zhu G, Huang Q, Zheng W, Huang Y, Hua J, Yang S, Zhuang J, Wang J, Chang J, Xu J, Ye J: LPS Upregulated VEGFR-3 Expression Promote Migration and Invasion in Colorectal Cancer via a Mechanism of Increased NF-kappaB Binding to the Promoter of VEGFR-3.Cell Physiol Biochem 2016;39:1665-1678.

21 Lo Nigro C, Ricci V, Vivenza D, Granetto C, Fabozzi T, Miraglio E, Merlano MC: Prognostic and predictive biomarkers in metastatic colorectal cancer anti-EGFR therapy. World J Gastroenterol 2016;22:6944-6954.

22 Chen S, Li X, Chen R, Yin M, Zheng Q: Cetuximab intensifies the ADCC activity of adoptive NK cells in a nude mouse colorectal cancer xenograft model. Oncol Lett 2016;12:1868-1876.

23 Veluchamy JP, Spanholtz J, Tordoir M, Thijssen VL, Heideman DA, Verheul HM, de Gruijl TD, van der Vliet HJ: Combination of NK Cells and Cetuximab to Enhance Anti-Tumor Responses in RAS Mutant Metastatic Colorectal Cancer. PLoS One 2016;11:e0157830.

24 Lo Nigro C, Ricci V, Vivenza D, Monteverde M, Strola G, Lucio F, Tonissi F, Miraglio E, Granetto C, Fortunato M, Merlano MC: Evaluation of antibody-dependent cell-mediated cytotoxicity activity and cetuximab response in KRAS wild-type metastatic colorectal cancer patients. World J Gastrointest Oncol 2016;8:222230.

25 Houot R, Kohrt H: CD137 stimulation enhances the vaccinal effect of anti-tumor antibodies. Oncoimmunology 2014;3:e941740.

-26 Chaudhry A, Samstein RM, Treuting P, Liang Y, Pils MC, Heinrich JM, Jack RS, Wunderlich FT, Bruning JC, Muller W, Rudensky AY: Interleukin-10 signaling in regulatory T cells is required for suppression of Th17 cell-mediated inflammation. Immunity 2011;34:566-578.

27 Jones LL, Alli R, Li B, Geiger TL: Differential T Cell Cytokine Receptivity and Not Signal Quality Distinguishes IL-6 and IL-10 Signaling during Th17 Differentiation. J Immunol 2016;196:2973-2985.

28 Kaur K, Cook J, Park SH, Topchyan P, Kozlowska A, Ohanian N, Fang C, Nishimura I, Jewett A: Novel Strategy to Expand Super-Charged NK Cells with Significant Potential to Lyse and Differentiate Cancer Stem Cells: Differences in NK Expansion and Function between Healthy and Cancer Patients. Front Immunol 2017;8:297.

29 Zhou M, Yu P, Qu J, Chen Y, Zhou Y, Fu L, Zhang J: Efficacy of Bevacizumab in the First-Line Treatment of Patients with RAS Mutations Metastatic Colorectal Cancer: a Systematic Review and Network MetaAnalysis. Cell Physiol Biochem 2016;40:361-369. 


\section{Cellular Physiology Cell Physiol Biochem 2017;44:1038-1050

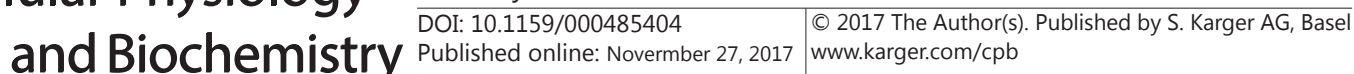 \\ Wang et al.: Immunological Characteristics of Cetuximab Treatment in CRC}

30 Wang Z, Liang L, Yu Y, Wang Y, Zhuang R, Chen Y, Cui Y, Zhou Y, Liu T: Primary Tumour Resection Could Improve the Survival of Unresectable Metastatic Colorectal Cancer Patients Receiving BevacizumabContaining Chemotherapy. Cell Physiol Biochem 2016;39:1239-1246.

-31 Yang X, Zhang X, Mortenson ED, Radkevich-Brown O, Wang Y, Fu Y-X: Cetuximab-mediated Tumor Regression Depends on Innate and Adaptive Immune Responses. Molecular Therapy 2013;21:91-100.

-32 Canossi A, Aureli A, Del Beato T, Rossi P, Franceschilli L, De Sanctis F, Sileri P, di Lorenzo N, Buonomo O, Lauro D, Venditti A, Sconocchia G: Role of KIR and CD16A genotypes in colorectal carcinoma genetic risk and clinical stage. J Transl Med 2016;14:239.

-33 Diao H, Iwabuchi K, Li L, Onoe K, Van Kaer L, Kon S, Saito Y, Morimoto J, Denhardt DT, Rittling S, Uede T: Osteopontin regulates development and function of invariant natural killer T cells. Proc Natl Acad Sci U S A 2008;105:15884-15889.

34 Cheng M, Chen Y, Xiao W, Sun R, Tian Z: NK cell-based immunotherapy for malignant diseases. Cell Mol Immunol 2013;10:230-252.

-35 Lee SC, Srivastava RM, Lopez-Albaitero A, Ferrone S, Ferris RL: Natural killer (NK): dendritic cell (DC) cross talk induced by therapeutic monoclonal antibody triggers tumor antigen-specific T cell immunity. Immunol Res 2011;50:248-254.

-36 Melero I, Johnston JV, Shufford WW, Mittler RS, Chen L: NK1.1 cells express 4-1BB (CDw137) costimulatory molecule and are required for tumor immunity elicited by anti-4-1BB monoclonal antibodies. Cell Immunol 1998;190:167-172.

-37 Chen J, Wei Y, He J, Cui G, Zhu Y, Lu C, Ding Y, Xue R, Bai L, Uede T, Li L, Diao H: Natural killer T cells play a necessary role in modulating of immune-mediated liver injury by gut microbiota. Sci Rep 2014;4:7259.

-38 Murillo O, Arina A, Hervas-Stubbs S, Gupta A, McCluskey B, Dubrot J, Palazon A, Azpilikueta A, Ochoa MC, Alfaro C, Solano S, Perez-Gracia JL, Oyajobi BO, Melero I: Therapeutic antitumor efficacy of anti-CD137 agonistic monoclonal antibody in mouse models of myeloma. Clin Cancer Res 2008;14:6895-6906.

39 Yang J, He J, Lu H, Wei L, Li S, Wang B, Diao H, Li L: Molecular features of the complementarity determining region 3 motif of the $\mathrm{T}$ cell population and subsets in the blood of patients with chronic severe hepatitis B. J Transl Med 2011;9:210.

40 Li S, Schmitz KR, Jeffrey PD, Wiltzius JJ, Kussie P, Ferguson KM: Structural basis for inhibition of the epidermal growth factor receptor by cetuximab. Cancer Cell 2005;7:301-311.

41 Qin J, Chen JX, Zhu Z, Teng JA: Genistein inhibits human colorectal cancer growth and suppresses miR-95, Akt and SGK1 Cell Physiol Biochem 2015;35:2069-2077.

-42 Janakiram NB, Mohammed A, Bryant T, Zhang Y, Brewer M, Duff A, Biddick L, Singh A, Lightfoot S, Steele VE, Rao CV: Potentiating NK cell activity by combination of Rosuvastatin and Difluoromethylornithine for effective chemopreventive efficacy against Colon Cancer. Sci Rep 2016;6:37046.

43 Pahl JHW, Ruslan SEN, Buddingh EP, Santos SJ, Szuhai K, Serra M, Gelderblom H, Hogendoorn PCW, Egeler RM, Schilham MW, Lankester AC: Anti-EGFR Antibody Cetuximab Enhances the Cytolytic Activity of Natural Killer Cells toward Osteosarcoma. Clin Cancer Res 2012;18:432-441.

-44 Hou H, Mao L, Wang J, Liu W, Lu Y, Yu J, Zhou Y, Mao L, Wang F, Sun Z: Establishing the reference intervals of NK cell functions in healthy adults. Hum Immunol 2016;77:637-642. 